\title{
E-Commerce Adoption
}

\section{E-Service Quality and Corporate Image on Customer Perception}

\author{
Rizqy Aji Nugroho
}

2301912776

LB21

\section{Introduction}

Pesatnya perkembangan teknologi mengakibatkan persaingan di bidang bisnis tidak dapat dihindari, sehingga perusahaan perlu mengetahui langkah-langkah yang tepat agar tetap bertahan dan mampu bersaing dengan perusahaan lain yang sejenis. Salah satu langkah yang dapat dilakukan perusahaan adalah dengan menerapkan teknologi pada proses bisnisnya. Teknologi sudah menjadi kebutuhan masyarakat. Penerapan teknologi diharapkan dapat mempermudah, mempercepat proses transaksi, menghemat biaya, waktu, tenaga dan dapat menjangkau pasar yang lebih luas. Turban et all (2012), membagi keuntungan penerapan elektronik atau teknologi dalam proses bisnis menjadi dua, bagi perusahaan dan pelanggan. Manfaat bagi perusahaan adalah memperluas jangkauan pasar menjadi pasar nasional dan internasional, mengurangi biaya pemrosesan, distribusi dan penarikan informasi yang akurat dan real-time. Sedangkan keuntungan bagi pelanggan seperti akses 24 jam ke sejumlah besar barang dan jasa. Liputan6.com (2018), mencatat perkembangan e-commerce sebesar 26,2 juta dan Alibaba merupakan perusahaan ecommerce terbesar untuk saat ini. Badan Pusat Statistik (BPS) mencatat telah terjadi peningkatan jumlah perusahaan yang menerapkan eCommerce di Indonesia dalam 10 tahun terakhir tumbuh menjadi sekitar 17. Dengan demikian, Indonesia Pasar e-Commerce berpeluang untuk tumbuh lebih besar lagi dengan jumlah penduduk terbesar dan tingkat produk domestik bruto (PDB) terbesar di ASEAN. Perusahaan ini bergerak di bidang penjualan produk alat keamanan seperti CCTV, fire alarm, public address system, conference system, intrusion alarm dan access control system sejak tahun 2000. Sutojo (2011), adapun manfaat dari citra perusahaan yang baik dan kuat yang memiliki daya saing jangka menengah dan panjang; menjadi tameng selama masa krisis, menarik eksekutif yang andal, di mana eksekutif yang andal adalah aset perusahaan; meningkatkan efektivitas strategi pemasaran, menghemat biaya operasional. Oleh karena itu, akan lebih baik bagi perusahaan untuk mengetahui apa persepsi pelanggan tentang teknologi tersebut terutama dalam hal peningkatan kualitas layanan berbasis elektronik dan citra perusahaan.

Beberapa studi negara berkembang yang mengacu pada adopsi e-commerce di UKM memerlukan pengetahuan tentang bagaimana konteks ini disajikan. Tujuan dari penelitian ini menjawab kebutuhan ini dan berusaha untuk menentukan variabel yang mempengaruhi adopsi e-commerce di UKM. Alat ukur (IMAES) diterapkan menggunakan kuesioner digital; 263 survei dikumpulkan di UKM dan data dianalisis menggunakan metodologi kuadrat terkecil parsial, alat validasi, dan model. Hasil penelitian menemukan bahwa UKM mengadopsi e-commerce karena tekanan dari manajemen senior, ekspektasi kinerja, keunggulan kompetitif yang ditawarkan, dan tekanan dari 
pelanggan mereka. Ini adalah salah satu studi pertama di kawasan yang secara empiris menganalisis adopsi e-commerce, serta menggambarkan kerangka teoritis.

\section{Literature Review}

Ushantha et all (2014), berpendapat bahwa pengukuran beberapa poin diperlukan untuk mendapatkan pemahaman yang komprehensif tentang persepsi pelanggan terhadap kualitas dan kepuasan layanan. Mmutle (2017), percaya bahwa pelanggan memiliki harapan yang tinggi terhadap kualitas layanan baik berbasis tradisional maupun modern. Ryu et al (2012), menunjukkan bahwa kualitas layanan menentukan citra perusahaan. Muyeed (2012), dalam studinya, menunjukkan bahwa persepsi pelanggan dapat bervariasi sesuai dengan sifat layanan.

\section{E-Commerce}

E-Commerce adalah sebuah konsep yang telah mengubah alur kehidupan manusia; e-commerce juga dapat dikatakan sebagai tolak ukur utama dari revolusi teknologi informasi dan komunikasi, khususnya di bidang ekonomi. Pernyataan tersebut didukung oleh Shahriari \& Gheiji (2015), yang mengatakan e-commerce adalah suatu proses pertukaran atau jasa dengan menggunakan jaringan internet. Berkat adanya internet, perkembangan teknologi telah memunculkan berbagai peluang baru dalam bisnis. Ecommerce adalah salah satunya. Karena pengertian e-commerce tersebut, terkadang ada kesalahpahaman tentang ecommerce dan marketplace. Istilah ecommerce digunakan untuk mendeskripsikan semua transaksi yang memakai media elektronik. E-commerce terdapat 6 jenis yaitu B2B, B2C, C2C, C2B, B2A dan C2A.

- Business to business (B2B) - Jenis e-commerce dimana sebuah perusahaan menjual produk atau jasa kepada perusahaan lainnya. Dalam model ecommerce ini, biasanya pembeli memesan barang dalam jumlah besar. Contohnya adalah sebuah perusahaan yang membeli perlengkapan kantor dari sebuah produsen.

- Business to consumer (B2C) - Dalam jenis ecommerce ini, sebuah perusahaan menjual produk atau jasa kepada konsumen. Pada umumnya, pelanggan dalam ecommerce B2C hanya mengecer. Jika anda pernah membeli dari suatu toko online, aktivitas tersebut termasuk dalam golongan ini.

- Consumer to consumer (C2C) - Pernah menjual barang bekas ke orang lain yang membutuhkannya melalui internet? Aktivitas tersebut termasuk dalam jenis e-commerce ini. Dengan kata lain, C2C adalah transaksi online antara dua individu.

- Consumer to business (C2B) - Berkebalikan dengan B2C, ecommerce C2B adalah skenario di mana seseorang menjual produk atau layanan kepada sebuah perusahaan. Seorang graphic designer, misalnya, menawarkan dan menjual logo buatannya kepada sebuah bisnis makanan.

- Business to public administration (B2A) - Model ecommerce ini mirip dengan B2B, tetapi pelakunya adalah bisnis dan lembaga pemerintah. Contoh B2A adalah jasa pembuatan website untuk sistem administrasi online. 
- Consumer to public administration (C2A) - Jenis ecommerce satu ini berjalan seperti C2B. Namun, transaksi dilakukan oleh individu dan lembaga pemerintah. Ecommerce dengan model $\mathrm{C} 2 \mathrm{~A}$ jarang ditemui di Indonesia. Jenis transaksi yang terjadi biasanya berbentuk jasa.

\section{E-service Quality}

Armstrong et al (2014), menyatakan bahwa ada empat karakteristik pelayanan: service intangibility, yaitu pelayanan yang tidak dapat diketahui dan dirasakan oleh pelanggan sebelum pelanggan membeli barang atau jasa yang ditawarkan perusahaan sehingga pelanggan harus melakukan persepsi tentang layanan yang akan diterima; ketidakstabilan layanan adalah layanan yang tidak dapat dipisahkan dari penyedia layanan; variabilitas layanan, yaitu kualitas layanan akan ditentukan oleh siapa orang tersebut memberikan layanan, kapan layanan tersebut diberikan, di mana layanan tersebut diberikan, dan bagaimana layanan tersebut diberikan; service perishability, yaitu jasa tidak dapat disimpan untuk dijual kemudian. Salah satu perbedaan antara perusahaan yang satu dengan perusahaan sejenis lainnya adalah kualitas pelayanan yang diberikan (Sood, 2012). Sood juga menyatakan bahwa ada tiga dimensi kualitas layanan: kualitas desain, yaitu karakteristik suatu barang atau jasa yang akan sangat dipengaruhi oleh perancang yang menentukan fitur kualitas ke dalam produk atau jasa; kualitas kesesuaian, yaitu tingkat kesesuaian produk atau jasa untuk memenuhi spesifikasi yang ditentukan oleh perancang; kualitas kinerja yaitu kualitas kinerja baik produk maupun jasa. Kegunaannya diukur dengan menjalankan fungsifungsi yang terkandung dalam produk dalam kondisi yang diketahui sehingga tingkat kegunaan dan daya tahan produk akan membentuk citra baik atau buruk bagi produk atau layanan.

\section{Corporate Image}

Sutojo (2011); Khvtisiashvili (2012); Loudon et al (2014), citra perusahaan merupakan persepsi pelanggan terhadap perusahaan dan dapat bersifat positif atau negatif. Khvtisiashvili (2012), terdapat lima dimensi dalam citra perusahaan yaitu corporate identity merupakan identitas suatu perusahaan yang dapat membedakannya dengan perusahaan pesaing sejenis; reputasi adalah karakter perusahaan yang meliputi manajemen, kredibilitas dan pelayanan yang berfokus pada kebutuhan pelanggan; kualitas perusahaan merupakan dimensi yang sangat penting karena mencakup kinerja perusahaan secara keseluruhan yang secara langsung mempengaruhi penciptaan citra perusahaan; kualitas fisik yang berkaitan dengan lingkungan nyata perusahaan selama melakukan kegiatan operasional; kualitas interaktif adalah hubungan interaksi antara karyawan perusahaan dan pelanggan. Beberapa faktor yang mempengaruhi tingkat keberhasilan perusahaan dalam membentuk citra perusahaan yang baik di mata pelanggan: menciptakan citra berdasarkan keinginan target bisnis perusahaan; memberikan manfaat melalui kualitas dan pelayanan yang diinginkan oleh masyarakat; citra yang baik bagi masyarakat dapat muncul dari bagaimana perusahaan menjalankan tanggung jawab sosial dan bagaimana perusahaan peduli terhadap lingkungan; kejujuran dapat menimbulkan kepercayaan pelanggan untuk membentuk citra yang baik bagi perusahaan; Citra perusahaan yang baik akan terlihat dari segala kegiatan yang dilakukan oleh perusahaan termasuk kegiatan dan prestasi yang telah dicapai oleh perusahaan.

\section{Customer Perception}


Kotler \& Keller (2012), persepsi pelanggan adalah pertukaran antara manfaat dan pengorbanan kinerja barang dan jasa. Sweeney \& Soutar; Mazzarol (2012), membagi persepsi pelanggan menjadi tiga dimensi:

1. Kualitas Fungsional, yaitu nilai kualitas suatu produk atau jasa merupakan salah satu faktor penting bagi konsumen untuk melakukan pembelian, jika barang atau jasa tersebut memiliki kualitas yang tinggi maka konsumen tidak akan segan-segan membayar mahal untuk memuaskan keinginannya.

2. Nilai Emosional. Selain melihat dari perspektif ekonomi, konsumen kini melihatnya dari perspektif konsumsi dimana kondisi psikologis mereka juga dapat terpenuhi.

3. Nilai Fungsional (Value for Money). Harga produk atau jasa menginterpretasikan nilai barang atau jasa dan sebagai faktor utama yang mempengaruhi konsumen dalam pengambilan keputusan. 


\section{Referensi:}

Lasmy, Saroso, H., Syahchari, D. H., Sudrajat, D., \& Herlina, M. G. (2019). E-service quality and corporate image on customer perception. International Journal of Innovation, Creativity and Change, 10(8), 284-294 